1309

\title{
水ミスト冷却による冷却効果の定量的評価に関する研究
}

\section{A study of the quantitative evaluation of the cooling effect by water mist coolants during grinding}

\author{
正 加藤 泰生（山口大理工院）， ○学 高㠃 靖規（山口大理工院），正 葛山 浩（山口大理工院）
}

Yasuo KATOH, Yamaguchi University, 2-16-1,Tokiwadai,Ube-shi, Yamaguchi, 755-0097 Japan

Yasunori TAKASAKI, Yamaguchi University, 2-16-1,Tokiwadai,Ube-shi, Yamaguchi, 755-0097 Japan

Hiroshi KATSURAYAMA, Yamaguchi University, 2-16-1,Tokiwadai,Ube-shi, Yamaguchi, 755-0097 Japan

Key Words: Water mist, Coolants, Evaporative, Latent heat, Additional materials $\left(\mathrm{C}_{6} \mathrm{H}_{7} \mathrm{O}_{6} \mathrm{Na}\right)_{n}$

\section{1. 緒言}

研削時に発生する熱の除去を目的として，研削油剤を使用 した様々な冷却方法が確立されてきた。しかし，この泠却方 法は，環境への悪影響などの問題点がある。そこで，本研究 では従来に比べ，環境負荷が小さく，同等以上の冷却効果を 得ることができるミスト冷却に注目し, 新しいクリーンな研 削技術の提案を目指している。これまでの研究では, 研削油 剂における「冷却効果」を水ミストで代替し，水ミストを研 削面に供給することで研削面での冷却ができることを示唆 した. ${ }^{(1) ま た, ~}$ 研削油剤における「潤滑」の機能については, 低濃度でも高い粘性が得られるアルギン酸ナトリウム(以下 化学式 $\left(\mathrm{C}_{6} \mathrm{H}_{7} \mathrm{O}_{6} \mathrm{Na}\right)_{\mathrm{n}}$ で表す)を加え, 水ミストの粘性を増加さ せることで，摩擦熱が抑制されることがわかった ${ }^{(2)}$. 但し, 潤滑効果は定量的に示したが，冷却効果は定量的に示してな かった，そこで，冷却作用を定量的に評価するためには，蒸

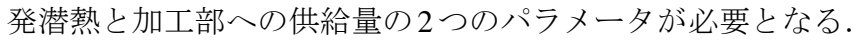
その為, まず蒸発潜熱を求める方法及び結果を評価し, 次に 冷却効果を定量的に評価していくことを本報では目的とし ている.

\section{2. 蒸発潜熱測定方法の原理及び測定手順}

\section{2-1. 方法 I}

溝田 ${ }^{(3)}$ によるゼオライトの水和熱測定に用いられた断熱 型水蒸気水和熱量計の原理を参照し，図 1 に示寸装置を製作 した．また，外気の影響を少なくするために恒温ボックス内 に装置を設置した，本方法を方法 I とする.

この装置では, 蒸発と凝縮の過程で潜熱が等しい事を利用 し，以下の手順で，蒸発潜熱を算出する.

まず, $\left(\mathrm{C}_{6} \mathrm{H}_{7} \mathrm{O}_{6} \mathrm{Na}\right)_{\mathrm{n}}$ 水溶液をヒーターで一定温度に加熱し 気化させ，周囲が水で覆われている真鍮の容器(図 1 におけ る A)の部分で凝縮させ，周囲と温度を均一にする。その際 に生じる潜熱 $\mathrm{L}$ と顕熱 $S$ を水の比熱と温度上昇で換算する. また，水の温度上昇に使われたエネルギ $Q$ は凝縮，水と均一 温度になる際に放出された顕熱の全エネルギの量と等しく なる. エネルギ $Q$ を凝縮量 $m$ で割り, 顕熱 $S$ を引くことで蒸発 潜熱 $\mathrm{L}$ は算出できる.よって, 以下の式で表すことができる.

$$
\begin{array}{ll}
Q=c_{w} M_{w} \Delta T+c_{b} M_{b} \Delta T & {[\mathrm{~J}]} \\
L=\frac{Q}{m}-S & {[\mathrm{~J} / \mathrm{g}]}
\end{array}
$$

但し, $M_{w}(=300 \mathrm{~g}), M_{b}(=333.9 \mathrm{~g})$ は水と真鍮それぞれの質量, $c_{w}, c_{b}$ は水と真鍮の比熱, $\Delta T$ は測定部の温度変化を表すも のである. 水及び真鍮の比熱, 質量は予め分かっているので,
測定部温度上昇及び凝縮された $\left(\mathrm{C}_{6} \mathrm{H}_{7} \mathrm{O}_{6} \mathrm{Na}\right)_{\mathrm{n}}$ 水溶液の質量を 測定すれば，蒸発潜熱を得ることができる。

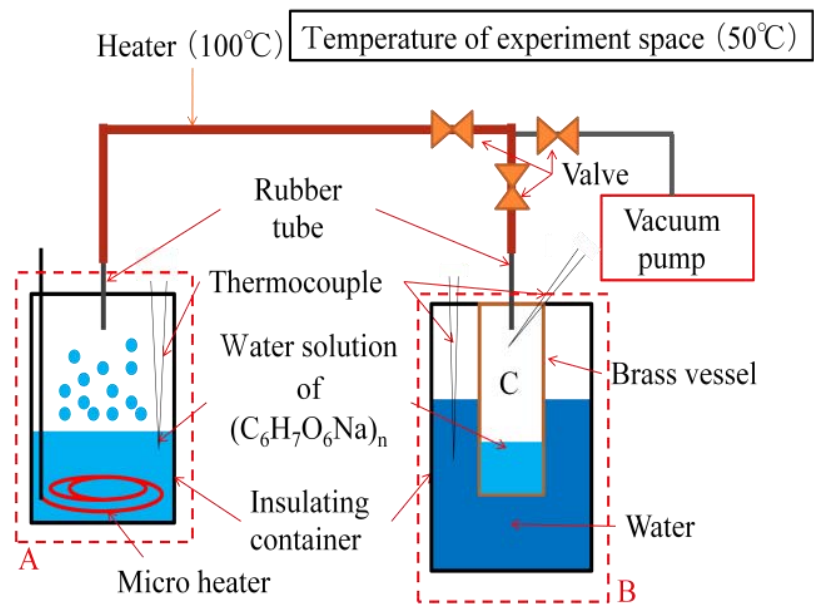

Fig. 1 Measuring equipment method I

\section{2-2. 方法 II}

蒸発による冷却量を直接測定する為に方法 II として図 2 に 示す装置を製作した．測定は， $\phi 60 \mathrm{~mm}$ ，厚さ $12.7 \mathrm{~mm}$ の銅円 板上であり, 水滴を落とした際, 蒸発気体の層が液体の下に 生じて熱伝導を阻害するため, 液体が瞬時に蒸発してしまう のを妨げるライデンフロスト現象が起こると考えられる為, 面中央には $\phi 60 \mathrm{~mm}$ ・深さ $4 \mathrm{~mm}$ の凹状のくぼみを作製した. また，銅円板の側面及び下面は，1 次元方向の熱流れとする 為, 断熱材であるルミボードを使用してある. 図.2の銅試験 片において×点に示される位置（中心から半径方向へ $10 \mathrm{~mm}$ 間隔の上面と下面 8 点) に $\mathrm{K}$ 型熱電対を設置し, データロガ 一により温度測定をする.

まず，マイクロヒーターで試験片を加熱し，その後加熱を 止め周囲一自然放熱を開始し温度測定を行う。一回目は基準 温度を測定するため $\left(\mathrm{C}_{6} \mathrm{H}_{7} \mathrm{O}_{6} \mathrm{Na}\right)_{\mathrm{n}}$ 水溶液は滴下せず，自然放 熱による温度変化をデータロガーにより記録した. この時の 温度変化を記録 1 とする. 冷却されたら再度試験片の加熱を 行い, 自然放熱を行う。自然放熱の間に $\left(\mathrm{C}_{6} \mathrm{H}_{7} \mathrm{O}_{6} \mathrm{Na}\right)_{\mathrm{n}}$ 水溶液 を 1 滴, 滴下寸る.この時の瞬時の温度変化をデータロガー 
により記録 2 として記録した.

次に，蒸発潜熱の算出方法について以下に示す．まず，記 録 1 と 2 を用いて, 溶液の滴下前後で生じる温度低下 $\Delta T$ を求 める. 求めた温度差に銅の熱容量Cを掛けて, $\left(\mathrm{C}_{6} \mathrm{H}_{7} \mathrm{O}_{6} \mathrm{Na}\right)_{\mathrm{n}}$ 水 溶液の供給量 $m$ で割り, 顕熱 $S$ を引くことで蒸発潜熱 $L$ を算出 する.よって, 蒸発潜熱は,

$$
L=\frac{C \Delta T}{m}-S \quad[\mathrm{~J} / \mathrm{g}]
$$

と表すことができる

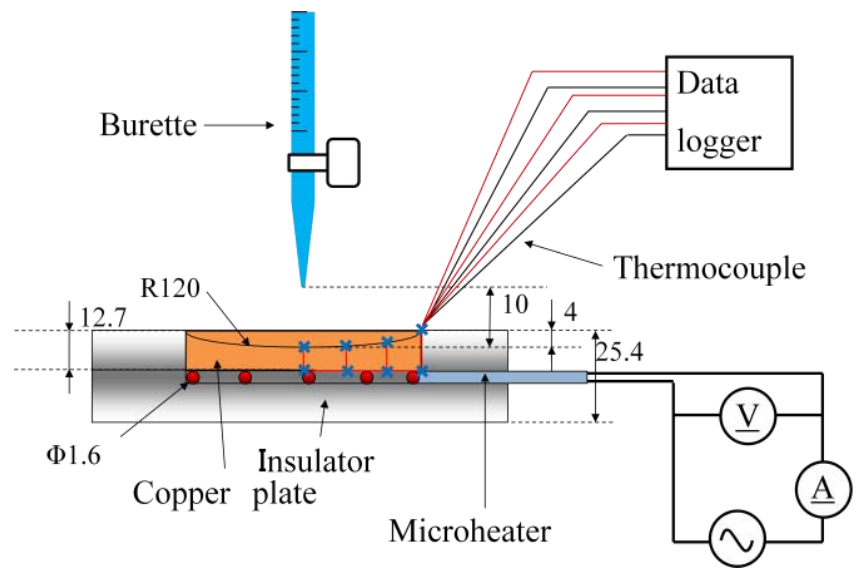

Fig. 2 Measuring equipment method II

\section{3. 実験結果及び考察}

実験結果は方法 I と II 共に図 3 に示す。 $\left(\mathrm{C}_{6} \mathrm{H}_{7} \mathrm{O}_{6} \mathrm{Na}\right)_{\mathrm{n}}$ は沸 点が大気圧で 494 496 ${ }^{\circ} \mathrm{C}$ と水に比べて非常に高いため, 蒸留 され水と同じ值をとると予想された。 しかし，方法 I の結果 は, $\left(\mathrm{C}_{6} \mathrm{H}_{7} \mathrm{O}_{6} \mathrm{Na}\right)_{n}$ 水溶液の蒸発潜熱の方が水に比べて $1 \sim 2$ 割 程度低い值となった。 $\left(\mathrm{C}_{6} \mathrm{H}_{7} \mathrm{O}_{6} \mathrm{Na}\right)_{\mathrm{n}}$ 水溶液の様に粘性のある 水溶液では, この測定方法 I の様に凝縮部から蒸発潜熱を算 出することは出来ないのではないかと考え, 蒸発部から直接 蒸発潜熱が測定可能な測定方法 II を試みた.

$\left(\mathrm{C}_{6} \mathrm{H}_{7} \mathrm{O}_{6} \mathrm{Na}\right)_{\mathrm{n}}$ 水溶液で行った実験より算出された蒸発潜熱 を図 3 に示す. 装置 I の值は約 $15 \%$ 低い值となるのに対し, 装置 II での実験結果の值は水の蒸発潜熱とほぼ同等を取る ことが分かった，必ずしも方法IIか良いとは言えないが，方 法 I は蒸気漏れ，定常状態維持の困難など問題点も多く，よ り信頼の足る值と思われる.

次に以前の研削実験における供給量 ${ }^{(2)} よ り ，$ 冷却効果をそ れぞれの濃度に関して算出し, 図 4 に示す. $\left(\mathrm{C}_{6} \mathrm{H}_{7} \mathrm{O}_{6} \mathrm{Na}\right)_{\mathrm{n}}$ 水 溶液の冷却効果は濃度が大きくなるにつれ，低下寸ることが 示唆された。 これは， $\left(\mathrm{C}_{6} \mathrm{H}_{7} \mathrm{O}_{6} \mathrm{Na}\right)_{\mathrm{n}}$ を添加することで溶液の 粘性が大きくなり超音波霧化器によるミスト発生量が小さ くなる為，それに伴い冷却効果も低下したと考えられる．更 に研削における被削物の温度低下は, $\left(\mathrm{C}_{6} \mathrm{H}_{7} \mathrm{O}_{6} \mathrm{Na}\right)_{\mathrm{n}}$ 水溶液の 蒸発潜熱及び顕熱により熱を奪う冷却効果と摩擦を低減し 発生熱を抑える潤滑効果から起因していると予想される.

これから， $\left(\mathrm{C}_{6} \mathrm{H}_{7} \mathrm{O}_{6} \mathrm{Na}\right)_{\mathrm{n}}$ 水溶液ミストでの冷却は水ミスト 冷却に比べ, 冷却効果は向上せず潤滑効果が大きく影響を与 えていることが考えられる. そこで次に, 潤滑効果に関して 算出を行った.

図 4 で示した冷却効果から被削材から流出する熱流束 $q_{c}$ を 算出し, 研削温度から逆問題解析 ${ }^{(2)}$ にって得た総合的減熱 量 $q_{s}$ との差が潤滑効果によるものだと仮定を置くことで潤 滑効果 $q_{l}$ を次式により定量的に見積もった.

$$
q_{l}=q_{s}-q_{c} \quad\left[\mathrm{~W} / \mathrm{mm}^{2}\right]
$$

と表すことができ，各加工条件での結果を表 1 に示す．表よ り有意な潤滑効果の存在が定量的に示される.

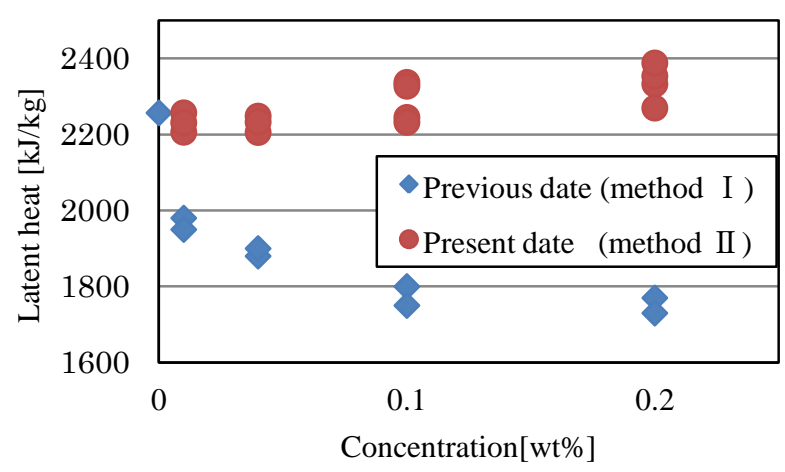

Fig. 3 Measuring result from method I , II

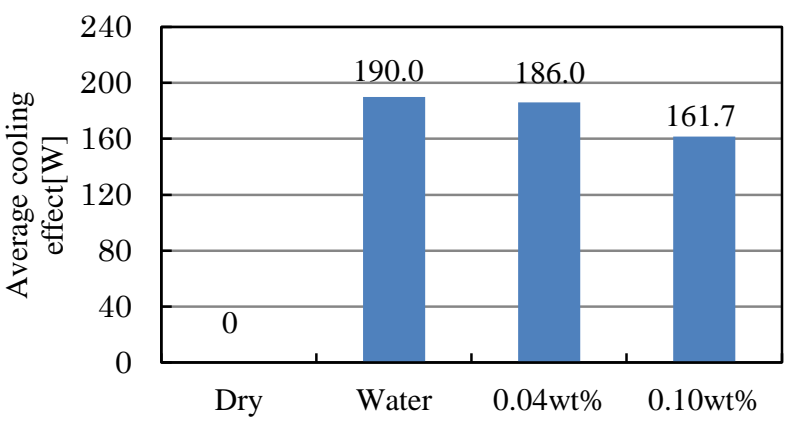

Fig. 4 cooling effect

Table 1 Among heat reduced cooling effect and lubricating effect

\begin{tabular}{|c|c|c|}
\hline & $\begin{array}{c}\text { Average } \\
\text { cooling } \\
\text { effect } \\
{\left[\mathrm{W} / \mathrm{mm}^{2}\right]}\end{array}$ & $\begin{array}{c}\text { Average } \\
\text { lubricating } \\
\text { effect } \\
{\left[\mathrm{W} / \mathrm{mm}^{2}\right]}\end{array}$ \\
\hline Dry & 0 & 0 \\
\hline Mist & 6.3 & 4.9 \\
\hline $\begin{array}{c}\text { Water solution of } \\
\left(\mathrm{C}_{6} \mathrm{H}_{7} \mathrm{O}_{6} \mathrm{Na}\right)_{\mathrm{n}} \\
(0.04[\mathrm{wt} \%])\end{array}$ & 6.2 & 22.2 \\
\hline $\begin{array}{c}\text { Water solution of } \\
\left(\mathrm{C}_{6} \mathrm{H}_{7} \mathrm{O}_{6} \mathrm{Na}\right)_{\mathrm{n}} \\
(0.1[\mathrm{wt} \%])\end{array}$ & 5.4 & 10.4 \\
\hline
\end{tabular}

\section{4. 結言}

本研究では，熱量計を作製し蒸発潜熱の測定を試み，研削 加工時の冷却効果を定量的に評価した。 その結果，水ミスト 加工, $\left(\mathrm{C}_{6} \mathrm{H}_{7} \mathrm{O}_{6} \mathrm{Na}\right)_{\mathrm{n}}$ 水溶液ミスト $(0.04 \mathrm{wt} \%)$ 加工で共に約 $6 \mathrm{~W} / \mathrm{mm}^{2}$ の冷却効果ありと評価できた。また，逆問題解析を 利用することで潤滑効果の存在が定量的に評価できること が分かった.

\section{参考文献}

（1）松尾·他 2 名，機講論，No.044 (2006), pp243

(2) 弓立一哉, 山口大学修士論文 (2009)

(3) 溝田忠人，日本セラミックス協会学術論文誌，Vol.109 (2001), pp874-881 